\title{
Precipitation change in Southern Italy linked to global scale oscillation indexes
}

\author{
T. Caloiero ${ }^{1}$, R. Coscarelli ${ }^{2}$, E. Ferrari ${ }^{3}$, and M. Mancini ${ }^{1}$ \\ ${ }^{1}$ Department of Environmental, Hydraulic, Infrastructures and Surveying Engineering (DIIAR), Politecnico of Milan, \\ Milan, Italy \\ ${ }^{2}$ National Research Council - Research Institute for Geo-Hydrological Protection (CNR-IRPI), Cosenza, Italy \\ ${ }^{3}$ Department of Soil Protection, University of Calabria, Cosenza, Italy
}

Received: 8 June 2010 - Revised: 1 February 2011 - Accepted: 2 February 2011 - Published: 15 June 2011

\begin{abstract}
This study investigates precipitation variability in five regions of Southern Italy (Campania, Apulia, Basilicata, Calabria and Sicily) using a homogeneous database of about 70 rain gauges with more than 50 years of observation. First, a statistical analysis was performed through the MannKendall non-parametric test in order to determine rainfall the trend on both yearly and seasonal scales. Then, the relationship between the rainfall and some teleconnection pattern indexes was investigated using Spearman's test. The results show remarkable statistically significant negative trends for annual and winter aggregations in most part of the series. Moreover, a strong correlation has emerged between the teleconnection patterns and precipitation in Southern Italy, particularly in winter and on the Tyrrhenian side of the study area.
\end{abstract}

\section{Introduction}

Extensive research on climate change, and on its potential, large-scale, environmental and economic consequences, has been carried out during the last 20 years. In particular, rainfall trend evaluations on large spatial scales have shown a significant increment in Northern and Central Asia, in the eastern parts of North and South America, and in Northern Europe (Sharma et al., 2000; Hamilton et al., 2001; Boyles and Raman, 2003). In contradistinction, growing dry conditions have been observed in the Sahel, in the Mediterranean area, in Southern Africa and Southern Asia (Hess et al., 1995; Liu et al., 2008; Lebel and Ali, 2009). Regarding the Mediter-

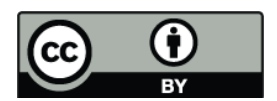

Correspondence to: E. Ferrari

(ferrari@dds.unical.it) ranean area, several studies have been carried out to investigate trends in annual and seasonal precipitation on a large scale (Kutiel et al., 1996; Piervitali et al., 1998; Xoplaki et al., 2006) and for entire nations or regions (Amanatidis et al., 1993; Esteban-Parra et al., 1998; De Luis et al., 2000; Feidas et al., 2007; Del Rio et al., 2010). These analyses often revealed negative trends for annual and winter precipitation. Long precipitation records were investigated in Northern and Central Italy (Montanari et al., 1996; De Michele et al., 1998; Brunetti et al., 2006b) and in Southern Italy (Palmieri et al., 1991; Brunetti et al., 2004, 2006a; Cotecchia et al., 2004). In particular, significant annual and winter negative precipitation trends have been reported for limited areas of southern Italian regions, as in the case of Campania (Diodato, 2007; Longobardi and Villani, 2010), Basilicata (Piccarreta et al., 2004), Calabria (Coscarelli et al., 2004; Ferrari and Terranova, 2004; Caloiero et al., 2011) and Sicily (Aronica et al., 2002; Cancelliere and Rossi, 2003; Cannarozzo et al., 2006).

Local changes in meteorological variables are mainly influenced by atmospheric circulation (Parker et al., 1994; Hurrel and Van Loon, 1997; Brunetti et al., 2002a): for this reason, planetary-scale indexes are used to investigate some phenomena of local climate variability. These indexes are based on the difference in sea level pressure between two geographic areas, called centres of climatic action. Such an approach, called teleconnection, shows that climatic conditions in different geographical areas, even when relatively far away from each other, are interdependent. The most important indexes are the Southern Oscillation Index (SOI), best known as El-Niño Southern Oscillation (ENSO), evaluated between Tahiti and Darwin on the opposite sides of the Pacific Ocean (Ropelewski and Jones, 1987), the North Atlantic Oscillation Index (NAOI), which represents fluctuations in the difference of pressure between the Azores area

Published by Copernicus Publications on behalf of the European Geosciences Union. 
and the Sea of Iceland (Hurrell, 1995; Hurrel and van Loon, 1997), numerous block indexes like the European Blocking Index (EBI), calculated between two points on the Atlantic Ocean (Wallace and Gutzler, 1981), and the Arctic Oscillation Index (AOI), defined as the leading Empirical Orthogonal Function (EOF) of the Northern Hemisphere sea-level pressure (SLP) anomalies poleword of $20^{\circ} \mathrm{N}$ weighted by area (Thompson and Wallace, 1998, 2000). In addition to these indexes, which represent the behaviour of the atmosphere on a large scale, there are others which are evaluated on a smaller regional scale, such as the Mediterranean Oscillation Index (MOI), calculated as the difference of pressure between the western and the eastern part of the Mediterranean basin (Conte et al., 1989); the Western European Zonal Circulation Index (WEZCI), proposed by Slonosky et al. (2001) and constructed from Madrid, Barcelona, Lund and Trondheim; the Mediterranean Circulation Index (MCI), defined by Brunetti et al. (2002b) as the normalised pressure difference between one station located in the North-western Mediterranean (Marseille) and another in the South-eastern Mediterranean (Jerusalem); and the Western Mediterranean Oscillation Index (WeMOI), calculated as the difference between the standardised values in surface atmospheric pressure in San Fernando (Spain) and Padua (Italy) (Martin-Vide and Lopez-Bustins, 2006).

Brunetti et al. (2002b) have analysed precipitation and wet days registered in Italy during the last half of the past century in relation to the NAOI, the WEZCI and the MCI. This study has demonstrated that the WEZCI and the MCI are more suitable for representing Italian precipitation variability since they capture a greater proportion of precipitation and wet day variance for all seasons. Specifically, the WEZCI is more representative of dry periods and the MOI more suitable for representing wet conditions. Martin-Vide and Lopez-Bustins (2006) consider the WeMOl significantly better than the NAOI to explain monthly pluviometric anomalies, and regard it as a useful tool to forecast torrential rainfall events in the northwestern zones of the Mediterranean (the eastern part of the Iberian Peninsula and the South of France).

In this study, we present the trend analysis of the annual and the seasonal rainfall series observed in Southern Italy during the period 1916-2003 and the evaluation of the influence of SLP anomalies on the pluviometric amounts. For the latter purpose, a correlation analysis between precipitation and some climatic indexes was performed using three indexes: the large scale NAOI, for its well known effects on European climate, and two local indexes, the WeMOI and the MCI, better centred on the Mediterranean basin. Finally, a composite analysis has been performed taking only the winter precipitation and the NAOI into account.

\section{Data and methodology}

The data sets gathered in the present study for the observation period 1916-2003 were collected from the hydrological reports of the former Hydrological Service. Given that some historical series lack information, especially during the World War II period (1940-1949), some data series were discarded when the number of years of observation was too low for statistical purposes (less than 50 years of observation data); then data was checked for homogeneities. Among the various methods used to solve homogeneity problems, there is currently no single objective one, and the choice of the most suitable procedure is strictly related to the data-set characteristics (metadata availability, station density, and so on) and to the region examined (Peterson and Easterling, 1994; Aguilar et al., 2003). The homogenization approach and the database used in this work is similar to the one discussed in Brunetti et al. (2010). Instead of using one single reference series (obtained, to say, as an average series of the neighbouring stations), each series was tested against other series by means of a multiple application of the Craddock test (Craddock, 1979) in sub-groups of 5 series. The break signals of one series against all others were then collected in a decision matrix and the breaks were assigned to the single series according to probability. Whenever a break needed to be corrected, the series used to estimate the adjustments was chosen among the neighbouring series, which resulted homogeneous in a sufficiently long sub-period centred on the break year, and which correlated well with the one to be corrected. Several series were chosen to estimate the adjustments required to improve their stability and to prevent unidentified outliers in the reference series from producing bad corrections.

The trend analysis was performed through the application of the simple non-parametric Mann-Kendall (MK) test. This test is a rank-based method for evaluating the presence of trends in time-series data without specifying whether the trend is linear or non-linear (Mann, 1945; Kendall, 1962). To quantify the trend, a parametric analysis through the linear regression (LR) on seasonal and annual rainfall was carried out.

The connections between precipitation and large-scale atmospheric patterns were investigated by means of the nonparametric Spearman's rank correlation test applied to the rainfalls and the climatic indexes (Spearman, 1904). Spearman's rank correlation coefficient $(\rho)$ is a special case of the Pearson's product-moment coefficient in which the data are converted to ranks and then the difference $D$ between the ranks is calculated for each pair of observations. The test is well suited for monotonically related variables, even when their relationship is not linear, as it is required in the case of Pearson's correlation coefficient. 
The coefficient $\rho$ is then given by:

$\rho=1-\frac{6 \sum D^{2}}{N\left(N^{2}-1\right)}$.

where $D$ is the difference between the ranks of corresponding values of the two variables, and $N$ is the number of pairs of values.

The statistical significance of the regression was checked by using the two-tailed test of the Student's t-distribution by evaluating the probability of rejecting the null hypothesis regarding the absence of any relationship for the values of $t$ with (N-2) degrees of freedom.

The values of the climatic indexes used in the study were provided by: the Climatic Research Unit (CRU) of the School of Environmental Sciences of the University of East Anglia in Norwich (http://www.cru.uea.ac.uk/cru/data/ pci.htm) for the NAOI, the Institute of Atmospheric Sciences and Climate (ISAC) of the Italian National Research Council (CNR) for the MCI, and the Group of Climatology of the University of Barcelona, Catalonia, Spain (http: //www.ub.edu/gc/English/wemo.htm) for the WeMOI.

With the aim to better assess the winter precipitation response to the climatic index variability, the composite normalised precipitation anomalies, corresponding to the extreme (negative and positive) NAOI phases, were computed for each station as presented by Türkeş and Erlat (2003). The composite analysis refers to a negative (or weak) climatic index anomaly phase corresponding to normalised index values $<-1\left(\mathrm{NAOI}^{-}\right)$and to a positive (or strong) climatic index anomaly phase corresponding to normalised index values $>+1\left(\mathrm{NAOI}^{+}\right)$. Each winter rainfall series, characterised by a mean value $P_{\mathrm{m}}$ and a standard deviation $\sigma$, was divided into two subseries corresponding to the two different climatic index anomaly phases. Then, for each subseries, the mean precipitation $\left(p_{\mathrm{m}}\right)$ and the Composite Normalized Anomalies (CNA), given by the ratio between the difference $\left(P_{\mathrm{m}}-p_{\mathrm{m}}\right)$ and the standard deviation $\sigma$, were calculated to provide evidence of the influence of the extreme NAOI phases on the winter precipitation amounts.

\section{Case study}

The hydrological series analysed in this work are the seasonal and the yearly rainfall data observed in five regions of Southern Italy (Campania, Apulia, Basilicata, Calabria and Sicily), which occupy a total area of about $85000 \mathrm{~km}^{2}$. As a result of the homogenisation procedure, 42 out of the 71 daily precipitation series were homogeneous, 26 were homogenised, and 3 were discarded because of their extremely low quality. Consequently, 68 rainfall series with an average density of 1 station per $1250 \mathrm{~km}^{2}$ were considered in this work (Fig. 1). The mean monthly rainfall distributions in the five regions clearly evidence the typical characteristics of the Mediterranean regime, with lower values observed in the summer period and higher values recorded during autumn and winter (Fig. 2). In summer, the Azores anticyclone, extending over Southern Italy, favours a rather dry and temperate climate, while breeze circulations develop on the coast and inland (Federico et al., 2000). In winter, fall and spring, when the Azores anticyclone retreats and the Siberian high extends over Northern Europe and Scandinavia, the Mediterranean cyclone develops, reaches Southern Italy and determines a colder and more humid climate than in the summer. In most parts of Southern Italy, orography controls the rainfall amount and distribution over the regions, as found only for the Calabria region by Colacino et al. (1997), who also showed that the interaction between the orography and mesoscale circulations leads to a precipitation gradient between the eastern and western side of the peninsula. Numerical simulations of severe weather showed the crucial role played by orography, which enhances rainfall in localised spots (Federico et al., 2003a, b) or forces secondary cyclogenesis persisting over the Ionian side of Southern Italy (Federico et al., 2007).

\section{Discussion}

In order to point out the temporal evolution of the precipitation in the study area, the percentage ratio of the moving 10year average rainfall to the average value of the last decade (1994-2003) of the whole observation period was calculated only for the annual, winter and summer precipitation (Fig. 3). A decreasing temporal evolution for the annual and, particularly, for winter rainfall is clearly shown, while a contrary, although weaker, behaviour emerges for summer precipitation. Quantitatively, the moving 10-year average rainfall values for the winter and the annual aggregations observed until the 1980 s are about $25 \%$ and $17 \%$ respectively higher than the corresponding average values of the 1994-2003 decade.

To evaluate the trend in each rain gauge, the MK test was applied to the annual and seasonal series. A prevailing negative trend was detected for all the temporal aggregations with the exception of summer rainfall, which presented a widespread, albeit not significant, positive trend (Fig. 4). Winter precipitation shows the most diffuse negative trend, approximately for $96 \%$ of the whole rain gauge set with $38 \%$ of significant results. A negative annual precipitation trend for $84 \%$ of the rain gauges was detected, significant for $40 \%$ of the whole series. No positive and significant trends were detected for the annual and the winter rainfalls. Minor percentages ( $9 \%$ and $18 \%$, respectively) of rain gauges presented a significant negative trend in spring and autumn. On the contrary, an increase in seasonal rainfall (for $73 \%$ of the whole rain gauge set; only $4 \%$ significant) was observed in the summer. Under the assumption of a linear trend, the spatial distributions of the results obtained through the regression analysis are quite similar for the annual and the winter rainfalls (Fig. 5), with the majority of the significant 


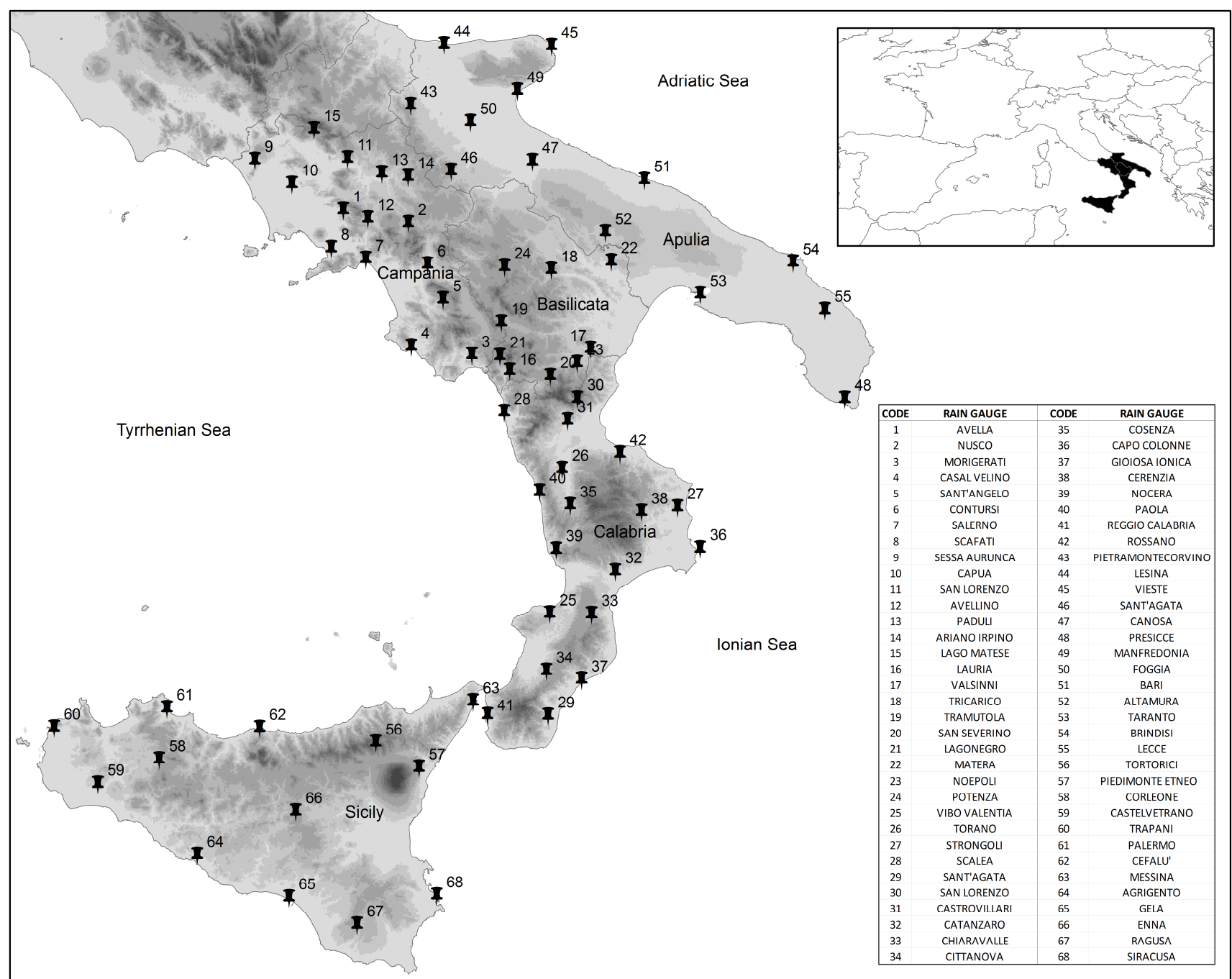

Fig. 1. Localization of the rain gauges used in the applications.

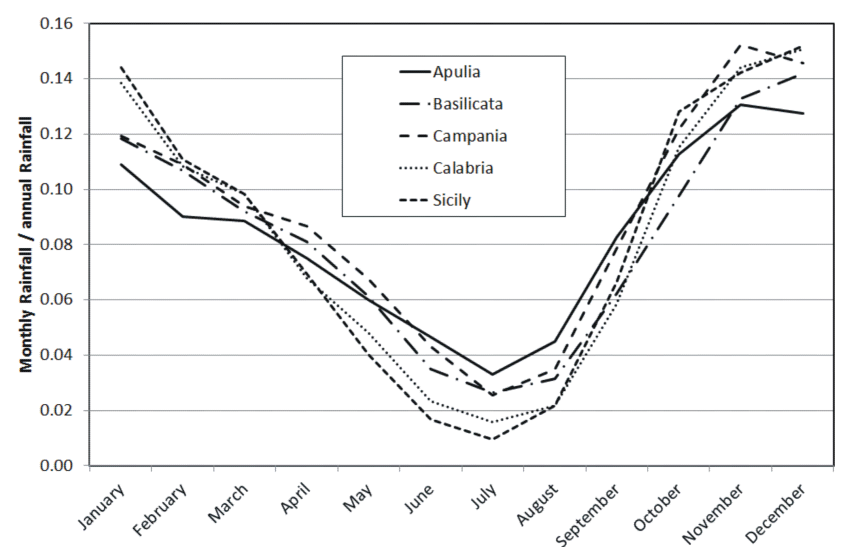

Fig. 2. Distributions of the ratios between the average monthly and annual rainfalls in the five regions of Southern Italy.

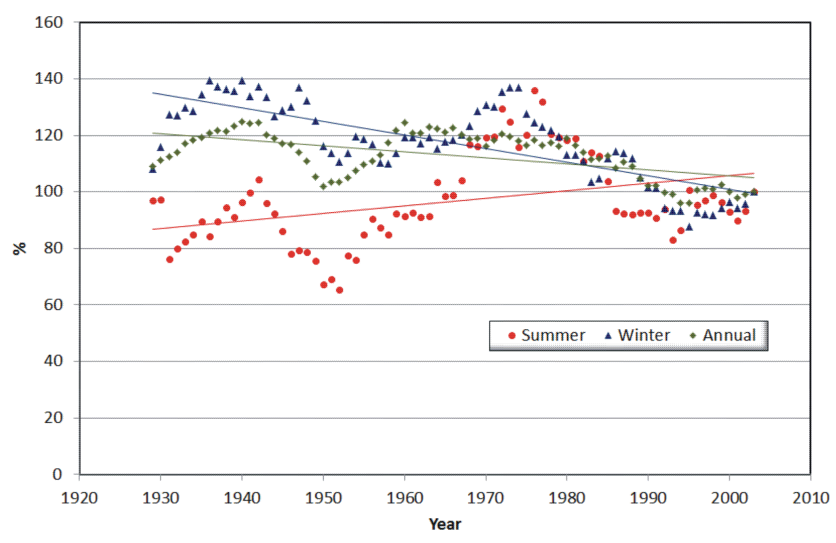

Fig. 3. Percentage ratios of the moving 10-year average rainfall to the average value of the decade 1994-2003 for the summer, the winter and the annual aggregations. 


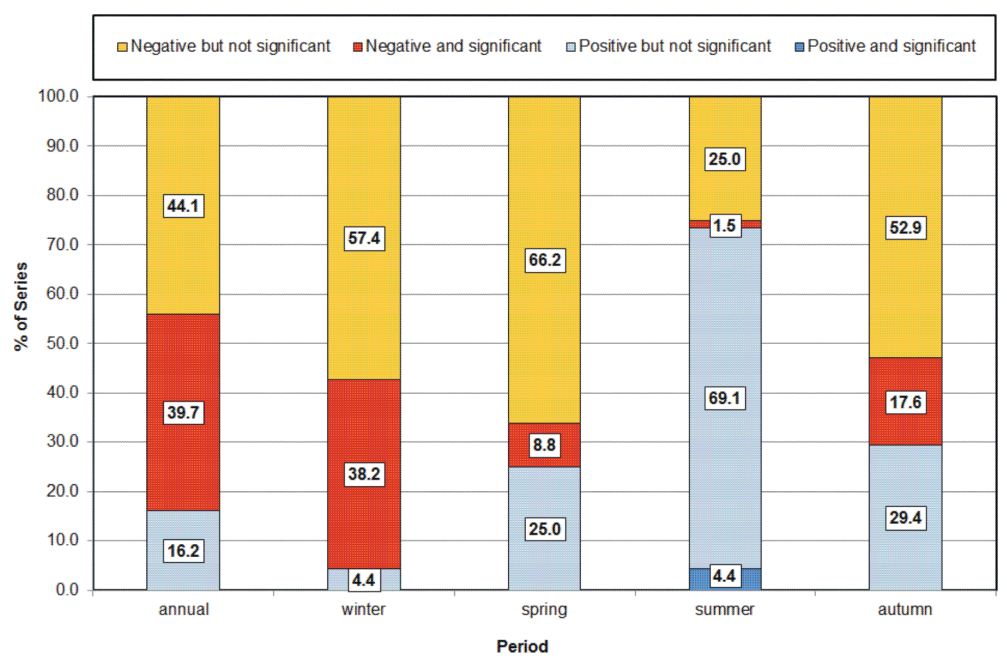

Fig. 4. Summary of the results obtained for the trends of the various time aggregations using MK test (total number of stations: 68).

values concentrated in Basilicata, Calabria and Sicily. In particular, considering only the significant trends evaluated through a linear regression, the average decrease is about $21 \mathrm{~mm} / 10$ years for annual precipitation and $12 \mathrm{~mm} / 10$ years for winter precipitation. The highest values are recorded in the Basilicata region at Lauria rain gauge (code 16) both for annual and winter precipitation: $-113 \mathrm{~mm} / 10$ years for the annual precipitation and $-61 \mathrm{~mm} / 10$ years for winter precipitation. High negative values were detected in the North and northwest sides of Sicily and in the central part of Calabria. The spatial distribution of the summer rainfall trend does not reveal any particular behaviour for both negative and positive values (Fig. 5).

A correlation analysis was performed between the seasonal precipitation and the climatic indexes (NAOI, WeMOI, MOI) evaluated in the corresponding seasonal periods. The best correlations were obtained for the data observed in the autumn (Fig. 6) and winter periods (Fig. 7). Regarding the correlations with the autumn data, the MCI provided the best results with the highest values of the correlation coefficients (up to 0.73) estimated at the rain gauges of Campania. A negative and significant correlation was obtained for almost all the rain gauges located on the Tyrrhenian side of the study area. Regarding the NAOI, a weaker correlation than the MCI was observed. On the contrary, the WeMOI showed a prevailing positive and non-significant correlation. As for the autumn season, the highest values of the correlation coefficient in winter were provided by the MCI (up to 0.62) mainly for the rain gauges of Campania, with negative and significant correlations all over the northern part of the examined area. For the NAOI, the significant negative correlation coefficients presented a more homogeneous distribution, even with lower values (up to 0.56) than the MCI. As regards the WeMOI, the values of the coefficient were higher than in autumn, with a prevailing positive correlation. The spatial variability of Spearman's coefficient between the eastern and western coasts of Southern Italy could depend on the orographic features (Apennine chain), which seem to affect the atmospheric circulation.

A composite analysis was performed on the NAOI and the winter rainfall because of the more homogeneous distribution of their statistically significant correlation coefficients (Fig. 7). The results evidence a clear link existing between the phase of the climatic index and the amount of winter rainfall. In fact, for almost all the rain gauges, rainfall anomalies present an opposite sign compared with the phase of the NAOI (Table 1). In particular, when the latter is negative, the average winter rainfall $\left(p_{\mathrm{m}}\right)$, for 63 out of 68 rain gauges, is greater than the average winter rainfall of the whole period $\left(P_{\mathrm{m}}\right)$, whereas the opposite happens when the NAOI is positive (Fig. 8). The highest absolute values of the CNA (up to +0.93 ) occur during the negative phase of the NAOI and are mainly localised in Campania. Moreover, it is important to note that the areas where the highest values of Spearman's coefficients are detected (i.e. the Tyrrhenian side of Campania and Northern Calabria), also present the highest values of CNA in the extreme (negative and positive) NAOI phases (Figs. 7 and 8). This is a further confirmation of the influence of the NAOI extreme phases on the precipitation amount in winter.

\section{Conclusions}

This study initially performed a statistical analysis of the seasonal and annual rainfall trends in the period 1916-2003 for a set of 68 rain gauges located in Southern Italy. The preliminary analysis of the data has shown that the average values of the annual and winter precipitation observed until the 1980s are higher than the corresponding average values of the last decade of the observation period (about $17 \%$ and $25 \%$, respectively). The analysis has evidenced significant negative 


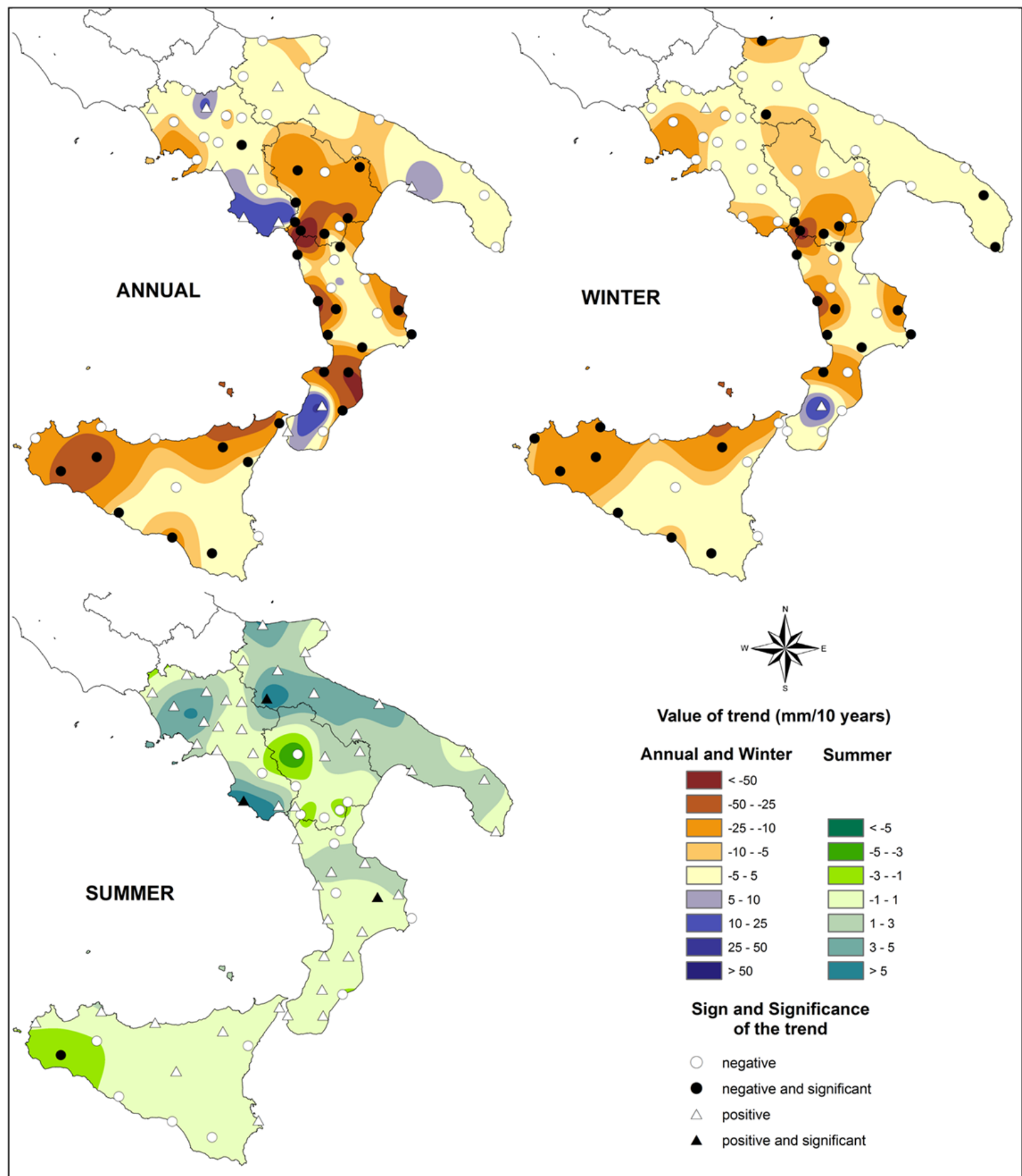

Fig. 5. Spatial distribution of trend values for the annual, winter and summer precipitation ( $\mathrm{mm} / 10$ years). For each rain gauge, the sign and the significance of the trend are evidenced through different symbols. 


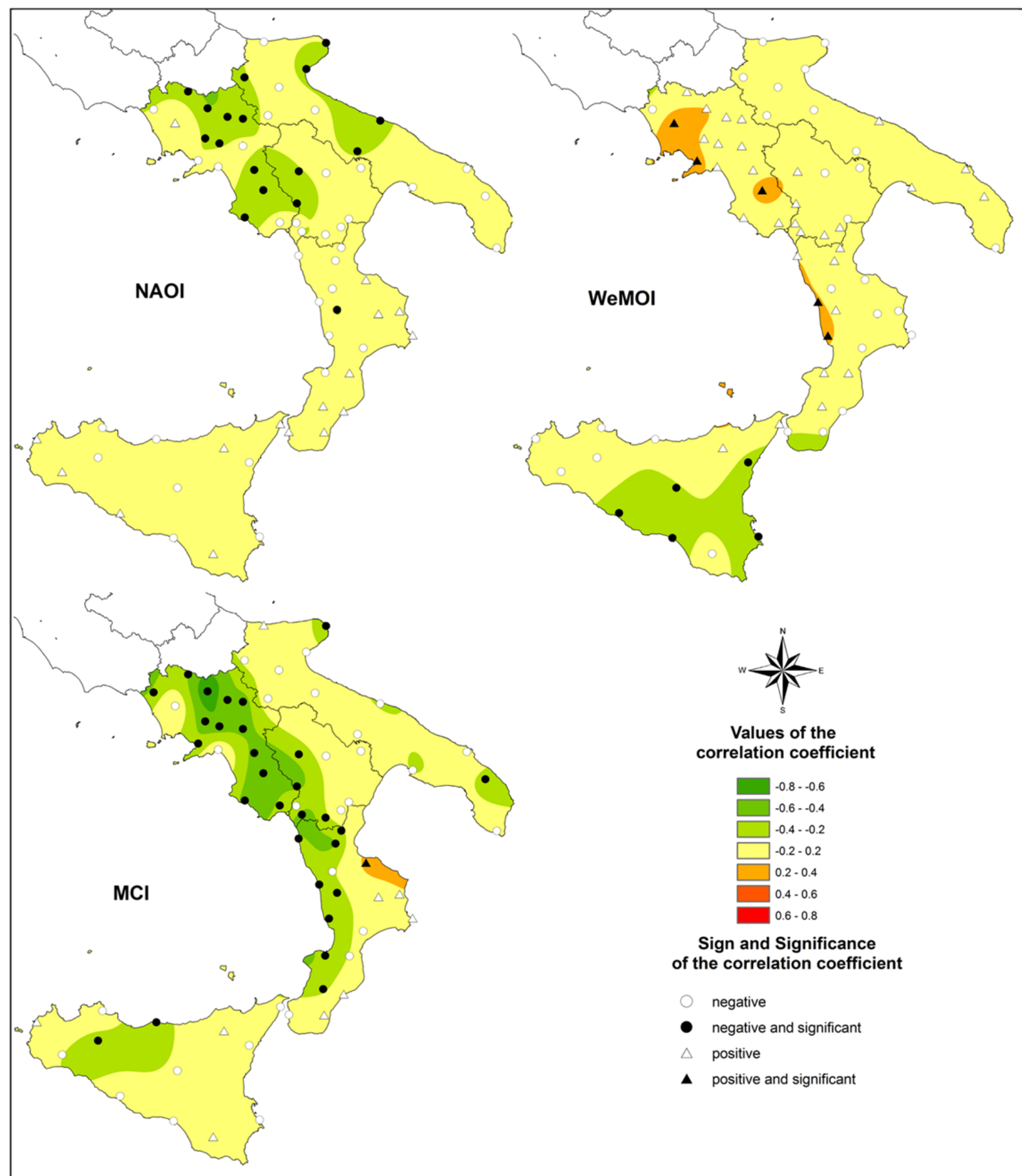

Fig. 6. Maps of Spearman's rank correlation coefficient between autumn precipitation and the climatic indexes. For each rain gauge, the sign and the significance of the correlation coefficient are evidenced through different symbols. 


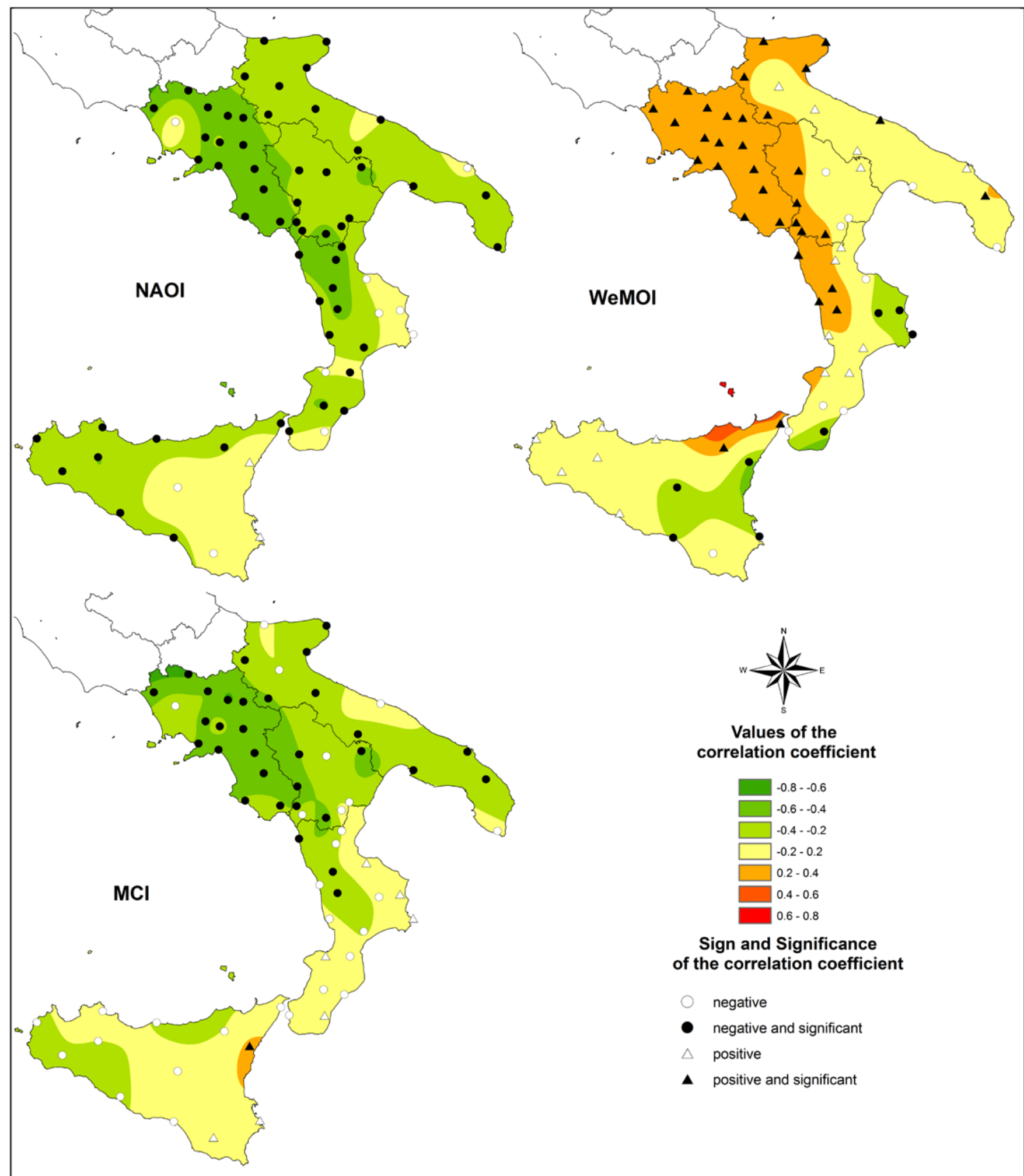

Fig. 7. Maps of Spearman's rank correlation coefficient between winter precipitation and the climatic indexes. For each rain gauge, the sign and the significance of the correlation coefficient are evidenced through different symbols. 


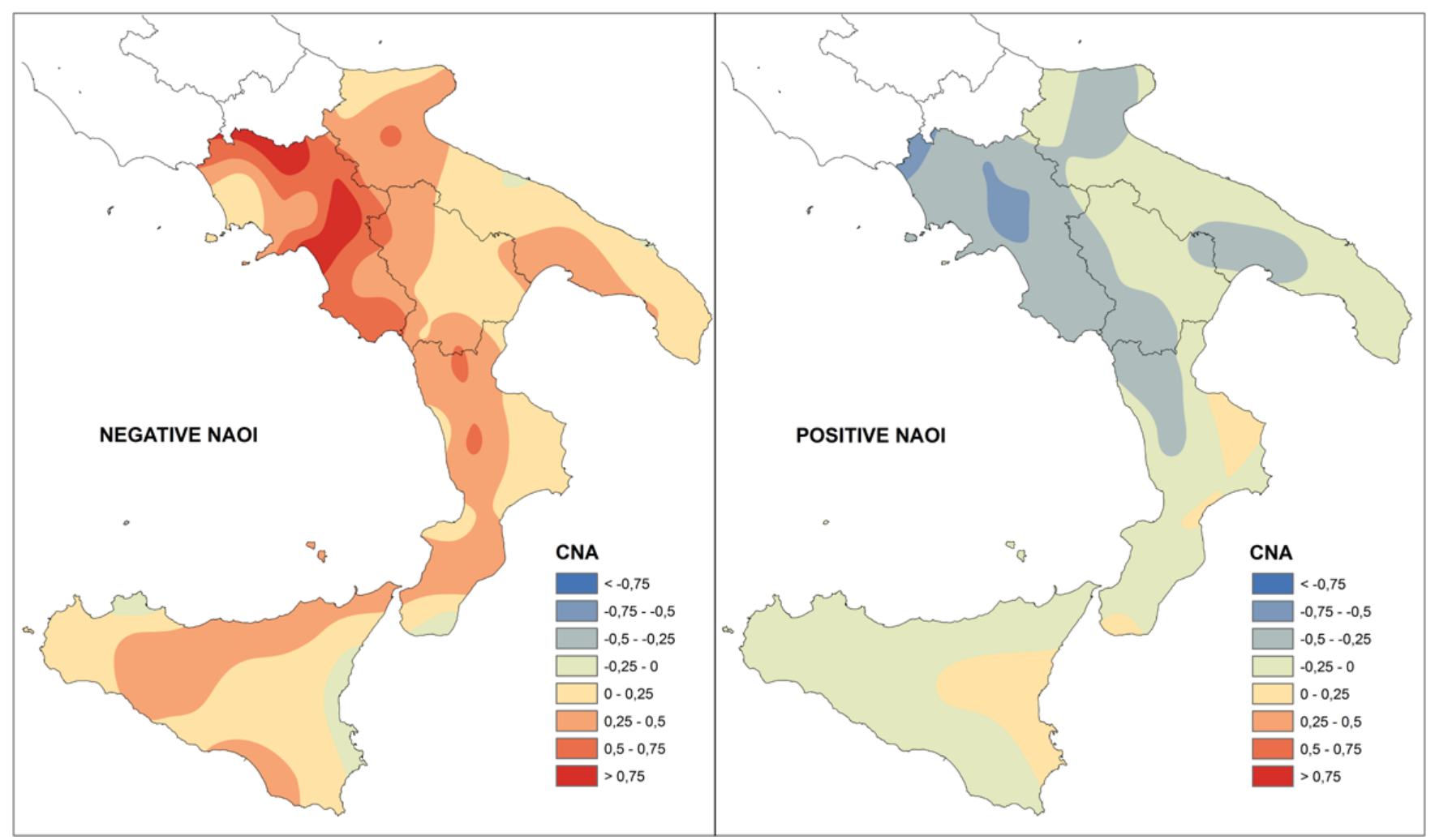

Fig. 8. Spatial distribution of the CNA for the winter precipitation, with reference to both the extreme negative phase $(<-1)$ and extreme positive phase $(>1)$ of the NAOI.

Table 1. Results of the composite analysis between the winter precipitation series and the NAOI. For each rain gauge, characterized by the long-term precipitation average $P_{\mathrm{m}}$ and the standard deviation $\sigma$ of the whole series, the CNA and the length of the subseries (n) were reported with reference both to the negative (NAOI) and the positive (NAOI ${ }^{+}$) extreme phases of the index. (Geographic Coordinate System: Monte Mario)

\begin{tabular}{|c|c|c|c|c|c|c|c|c|c|c|c|c|}
\hline \multirow[t]{2}{*}{ ID } & \multirow[t]{2}{*}{ Rain gauge } & \multirow[t]{2}{*}{ East } & \multirow[t]{2}{*}{ Nord } & \multirow{2}{*}{$\begin{array}{c}\text { Elevation } \\
\text { (ma.s.1.) }\end{array}$} & \multirow{2}{*}{$\begin{array}{l}\text { Starting } \\
\text { year }\end{array}$} & \multirow{2}{*}{$\begin{array}{c}\% \text { of } \\
\text { missing } \\
\text { data }\end{array}$} & \multirow[t]{2}{*}{$P_{\mathrm{m}}$} & \multirow[t]{2}{*}{$\sigma$} & \multicolumn{2}{|c|}{$\mathrm{NAOI}^{-}$} & \multicolumn{2}{|c|}{$\mathrm{NAOI}^{+}$} \\
\hline & & & & & & & & & CNA & $\mathrm{n}$ & CNA & $\mathrm{n}$ \\
\hline 1 & Avella & 2486346.54 & 4534316.03 & 198 & 1920 & 22.8 & 382.2 & 130.4 & 0.47 & 18 & -0.48 & 33 \\
\hline 2 & Nusco & 2527219.17 & 4526101.83 & 912 & 1921 & 18.7 & 400.9 & 153.7 & 0.93 & 17 & -0.45 & 37 \\
\hline 3 & Morigerati & 2567221.23 & 4443609.11 & 286 & 1920 & 12.3 & 536.9 & 181.5 & 0.69 & 18 & -0.49 & 43 \\
\hline 4 & Casal Velino & 2529210.77 & 4448831.84 & 189 & 1922 & 23.0 & 407.8 & 134.3 & 0.55 & 18 & -0.37 & 34 \\
\hline 5 & Sant'angelo & 2549148.48 & 4478391.07 & 557 & 1919 & 17.1 & 440.7 & 178.6 & 0.41 & 17 & -0.47 & 40 \\
\hline 6 & Contursi & 2539430.84 & 4500322.18 & 200 & 1919 & 19.5 & 450.0 & 169.3 & 0.65 & 14 & -0.47 & 29 \\
\hline 7 & Salerno & 2500479.91 & 4503705.98 & 16 & 1920 & 11.6 & 420.1 & 151.8 & 0.81 & 19 & -0.46 & 42 \\
\hline 8 & Scafati & 2478755.38 & 4510393.95 & 9 & 1919 & 21.2 & 304.7 & 111.7 & 0.39 & 18 & -0.35 & 36 \\
\hline 9 & Sessa Aurunca & 2430687.91 & 4565717.07 & 213 & 1919 & 25.5 & 343.2 & 123.1 & 0.48 & 17 & -0.54 & 32 \\
\hline 10 & Capua & 2453999.10 & 4550942.27 & 27 & 1920 & 26.9 & 292.5 & 109.7 & 0.10 & 14 & -0.31 & 30 \\
\hline 11 & San Lorenzo & 2488962.18 & 4566654.15 & 357 & 1920 & 23.7 & 372.8 & 126.2 & 0.87 & 16 & -0.51 & 34 \\
\hline 12 & Avellino & 2501762.94 & 4529019.45 & 383 & 1918 & 25.3 & 425.8 & 157.7 & 0.28 & 16 & -0.61 & 30 \\
\hline 13 & Paduli & 2510572.65 & 4557558.46 & 358 & 1920 & 24.6 & 230.0 & 93.4 & 0.65 & 16 & -0.43 & 33 \\
\hline
\end{tabular}


Table 1. Continued.

\begin{tabular}{|c|c|c|c|c|c|c|c|c|c|c|c|c|}
\hline \multirow[t]{2}{*}{ ID } & \multirow[t]{2}{*}{ Rain gauge } & \multirow[t]{2}{*}{ East } & \multirow[t]{2}{*}{ Nord } & \multirow{2}{*}{$\begin{array}{c}\text { Elevation } \\
\text { (m a.s.1.) }\end{array}$} & \multirow{2}{*}{$\begin{array}{l}\text { Starting } \\
\text { year }\end{array}$} & \multirow{2}{*}{$\begin{array}{c}\% \text { of } \\
\text { missing } \\
\text { data }\end{array}$} & \multirow[t]{2}{*}{$P_{\mathrm{m}}$} & \multirow[t]{2}{*}{$\sigma$} & \multicolumn{2}{|c|}{$\mathrm{NAOI}^{-}$} & \multicolumn{2}{|c|}{$\mathrm{NAOI}^{+}$} \\
\hline & & & & & & & & & CNA & $\mathrm{n}$ & CNA & $\mathrm{n}$ \\
\hline 14 & Ariano Irpino & 2527120.27 & 4555428.10 & 756 & 1919 & 17.5 & 185.1 & 75.9 & 0.75 & 16 & -0.47 & 39 \\
\hline 15 & Lago Matese & 2467912.59 & 4584908.86 & 1013 & 1920 & 22.3 & 517.7 & 184.0 & 0.87 & 18 & -0.43 & 35 \\
\hline 16 & Lauria & 2591057.00 & 4433718.00 & 630 & 1922 & 20.5 & 660.0 & 242.2 & 0.25 & 18 & -0.43 & 36 \\
\hline 17 & Valsinni & 2641868.00 & 4447319.00 & 250 & 1916 & 22.6 & 283.0 & 150.4 & 0.13 & 17 & -0.12 & 35 \\
\hline 18 & Tricarico & 2617168.00 & 4496921.00 & 698 & 1917 & 33.5 & 196.0 & 102.2 & 0.07 & 13 & -0.13 & 28 \\
\hline 19 & Tramutola & 2585761.00 & 4464153.00 & 654 & 1923 & 29.2 & 450.7 & 160.7 & 0.27 & 16 & -0.31 & 31 \\
\hline 20 & San Severino & 2616613.00 & 4430301.00 & 884 & 1922 & 21.0 & 672.5 & 228.6 & 0.46 & 16 & -0.49 & 24 \\
\hline 21 & Lagonegro & 2584925.00 & 4442935.00 & 666 & 1922 & 20.0 & 703.1 & 255.5 & 0.43 & 14 & -0.39 & 32 \\
\hline 22 & Matera & 2654879.00 & 4502213.00 & 450 & 1917 & 22.1 & 155.2 & 79.4 & 0.26 & 14 & -0.30 & 38 \\
\hline 23 & Noepoli & 2633381.00 & 4438561.00 & 676 & 1922 & 24.8 & 272.0 & 121.9 & 0.34 & 19 & -0.30 & 35 \\
\hline 24 & Potenza & 2587836.00 & 4498776.00 & 811 & 1916 & 5.2 & 242.2 & 104.4 & 0.42 & 18 & -0.23 & 46 \\
\hline 25 & Vibo Valentia & 2616243.00 & 4281550.00 & 498 & 1920 & 13.9 & 369.1 & 121.7 & 0.15 & 18 & -0.05 & 40 \\
\hline 26 & Torano & 2624039.00 & 4372283.00 & 97 & 1921 & 10.7 & 356.6 & 131.5 & 0.45 & 18 & -0.33 & 45 \\
\hline 27 & Strongoli & 2696613.00 & 4348132.00 & 342 & 1923 & 16.4 & 292.0 & 160.3 & 0.11 & 20 & 0.01 & 39 \\
\hline 28 & Scalea & 2587509.00 & 4407720.00 & 10 & 1922 & 8.9 & 374.7 & 136.5 & 0.46 & 20 & -0.31 & 42 \\
\hline 29 & Sant'agata & 2615164.00 & 4217548.00 & 440 & 1923 & 26.0 & 406.3 & 214.6 & 0.01 & 17 & -0.05 & 32 \\
\hline 30 & San Lorenzo & 2633635.00 & 4416254.00 & 851 & 1917 & 7.3 & 395.9 & 185.0 & 0.46 & 21 & -0.28 & 44 \\
\hline 31 & Castrovillari & 2627433.00 & 4402490.00 & 353 & 1920 & 10.5 & 323.1 & 128.5 & 0.51 & 19 & -0.41 & 40 \\
\hline 32 & Catanzaro & 2657511.00 & 4308078.00 & 334 & 1916 & 3.6 & 440.5 & 170.7 & 0.21 & 21 & -0.01 & 48 \\
\hline 33 & Chiaravalle & 2642566.00 & 4281247.00 & 714 & 1919 & 10.9 & 636.8 & 281.2 & 0.29 & 21 & 0.00 & 43 \\
\hline 34 & Cittanova & 2614160.00 & 4245441.00 & 407 & 1919 & 14.4 & 581.2 & 240.3 & 0.47 & 20 & -0.08 & 41 \\
\hline 35 & Cosenza & 2629133.00 & 4349377.00 & 242 & 1916 & 5.2 & 410.9 & 153.8 & 0.52 & 21 & -0.32 & 42 \\
\hline 36 & Capo Colonne & 2710815.31 & 4322274.94 & 24 & 1923 & 12.0 & 243.8 & 132.3 & 0.06 & 19 & -0.07 & 38 \\
\hline 37 & Gioiosa Ionica & 2636285.00 & 4240063.00 & 125 & 1916 & 11.8 & 367.8 & 162.8 & 0.38 & 20 & -0.15 & 38 \\
\hline 38 & Cerenzia & 2673913.99 & 4345199.84 & 663 & 1922 & 9.3 & 418.8 & 232.0 & 0.14 & 18 & 0.01 & 37 \\
\hline 39 & Nocera & 2620289.00 & 4321649.00 & 250 & 1923 & 9.8 & 680.4 & 212.5 & 0.37 & 20 & -0.12 & 39 \\
\hline 40 & Paola & 2609773.00 & 4358056.00 & 160 & 1925 & 15.3 & 421.4 & 154.0 & 0.12 & 19 & -0.10 & 40 \\
\hline 41 & Reggio Calabria & 2577069.00 & 4217981.00 & 15 & 1917 & 11.2 & 233.2 & 78.1 & 0.22 & 18 & -0.04 & 43 \\
\hline 42 & Rossano & 2660375.00 & 4381815.00 & 300 & 1916 & 19.8 & 337.6 & 141.6 & 0.21 & 20 & -0.01 & 38 \\
\hline 43 & Pietramontecorvino & 2528773.03 & 4600049.93 & 456 & 1928 & 20.0 & 272.6 & 90.9 & 0.28 & 19 & -0.13 & 35 \\
\hline 44 & Lesina & 2549755.58 & 4638200.02 & 5 & 1928 & 13.7 & 203.7 & 74.2 & 0.05 & 20 & -0.22 & 37 \\
\hline 45 & Vieste & 2617290.67 & 4637212.12 & 25 & 1921 & 5.7 & 199.7 & 99.7 & 0.26 & 19 & -0.23 & 45 \\
\hline 46 & Sant'agata & 2554146.37 & 4558959.69 & 791 & 1921 & 18.0 & 160.4 & 54.6 & 0.37 & 19 & -0.22 & 33 \\
\hline 47 & Canosa & 2605281.63 & 4564964.21 & 154 & 1922 & 7.3 & 166.1 & 70.7 & 0.28 & 20 & -0.17 & 44 \\
\hline 48 & Presicce & 2801820.46 & 4416051.39 & 114 & 1921 & 7.7 & 265.3 & 109.7 & 0.16 & 20 & -0.22 & 44 \\
\hline 49 & Manfredonia & 2595874.23 & 4609068.34 & 2 & 1921 & 9.8 & 125.3 & 53.2 & 0.32 & 19 & -0.28 & 42 \\
\hline 50 & Foggia & 2566321.85 & 4589613.20 & 74 & 1921 & 9.3 & 134.7 & 56.5 & 0.54 & 20 & -0.34 & 41 \\
\hline 51 & Bari & 2675747.69 & 4553399.33 & 12 & 1921 & 6.2 & 175.5 & 68.3 & 0.00 & 20 & -0.12 & 45 \\
\hline 52 & Altamura & 2651189.13 & 4520348.44 & 461 & 1921 & 7.1 & 154.8 & 68.6 & 0.09 & 20 & -0.23 & 43 \\
\hline 53 & Taranto & 2710921.24 & 4481630.45 & 15 & 1921 & 5.7 & 164.0 & 76.5 & 0.43 & 20 & -0.27 & 45 \\
\hline 54 & Brindisi & 2769299.26 & 4501560.46 & 28 & 1921 & 7.7 & 213.1 & 87.6 & -0.01 & 20 & -0.21 & 43 \\
\hline 55 & Lecce & 2789283.93 & 4471830.12 & 78 & 1921 & 6.2 & 219.8 & 86.0 & 0.20 & 20 & -0.24 & 45 \\
\hline 56 & Tortorici & 2506782.30 & 4200552.46 & 475 & 1921 & 2.5 & 448.5 & 148.6 & 0.30 & 19 & -0.05 & 40 \\
\hline 57 & Piedimonte Etneo & 2533972.74 & 4184731.76 & 348 & 1922 & 13.7 & 423.5 & 202.7 & -0.01 & 16 & 0.00 & 34 \\
\hline 58 & Corleone & 2370590.62 & 4189883.45 & 588 & 1917 & 8.9 & 301.5 & 101.2 & 0.39 & 20 & -0.14 & 43 \\
\hline 59 & Castelvetrano & 2331952.96 & 4174796.36 & 190 & 1919 & 11.2 & 240.7 & 85.6 & 0.07 & 19 & -0.17 & 42 \\
\hline 60 & Trapani & 2304427.55 & 4210057.83 & 2 & 1916 & 4.3 & 179.7 & 62.2 & 0.20 & 21 & -0.10 & 44 \\
\hline 61 & Palermo & 2375384.68 & 4222207.67 & 120 & 1916 & 14.6 & 375.0 & 142.5 & -0.15 & 19 & -0.09 & 37 \\
\hline 62 & Cefalu' & 2433652.44 & 4209832.13 & 30 & 1919 & 15.3 & 266.2 & 97.8 & 0.32 & 16 & -0.15 & 38 \\
\hline 63 & Messina & 2568014.86 & 4226484.28 & 54 & 1916 & 2.5 & 348.5 & 119.1 & 0.35 & 21 & -0.15 & 45 \\
\hline 64 & Agrigento & 2394460.92 & 4130219.22 & 175 & 1916 & 5.5 & 229.6 & 84.2 & 0.24 & 21 & -0.18 & 46 \\
\hline 65 & Gela & 2452163.56 & 4103452.47 & 30 & 1923 & 17.1 & 163.5 & 68.0 & 0.28 & 20 & -0.15 & 36 \\
\hline 66 & Enna & 2456479.54 & 4157541.47 & 950 & 1920 & 7.7 & 256.0 & 106.1 & 0.17 & 20 & 0.02 & 43 \\
\hline 67 & Ragusa & 2495077.16 & 4086416.66 & 515 & 1921 & 11.2 & 282.7 & 105.4 & 0.25 & 20 & -0.13 & 39 \\
\hline 68 & Siracusa & 2545114.40 & 4104759.93 & 9 & 1917 & 20.5 & 187.7 & 90.2 & -0.12 & 15 & 0.11 & 36 \\
\hline
\end{tabular}


trends for almost all seasonal rainfall, while a positive trend in summer rainfall has been observed. In particular, the analysis revealed an average decrease in both annual and winter precipitation (about $21 \mathrm{~mm} / 10$ years and $12 \mathrm{~mm} / 10$ years, respectively), with the highest values of $-113 \mathrm{~mm} / 10$ years for the annual precipitation and of $-61 \mathrm{~mm} / 10$ years for winter precipitation.

The correlation analysis between the rainfall and some teleconnection pattern indexes has provided significant results for the winter and the autumn periods, mainly in the case of the NAO and the MC indexes, with higher correlation coefficients observed especially for the rain gauges of the Tyrrhenian side of Campania region. A contrary relationship between the rainfall anomalies and the phase of the NAOI has emerged from the composite analysis, performed for the NAOI and the winter season. In particular, the average rainfall corresponding only to the negative NAOI phase is greater than the average rainfall of the whole observation period for the majority of the rain gauges, whereas the opposite occurs when the NAOI is positive. Moreover, the highest values of both Spearman's coefficient and the CNA values were observed in the same geographical areas (the Tyrrhenian side of Campania and Northern Calabria). These final results seem to confirm the influence of the western air currents on the behaviour of the rainfall regime of Southern Italy.

Acknowledgements. The authors thank M. Brunetti of the ISAC-CNR for kindly providing the data on the Mediterranean Circulation Index and the two reviewers (M. Maugeri and an anonymous one) for their useful comments. This work developed within the UNESCO MED-FRIEND project.

Edited by: R. Deidda

Reviewed by: M. Maugeri and another anonymous referee

\section{References}

Aguilar, E., Auer, I., Brunet, M., Peterson, T. C., and Wieringa, J.: Guidelines on Climate Metadata and Homogenization, World Climate Programme Data and Monitoring WCDMP-No.53, WMO-TD No. 1186, WMO, Geneva, 2003.

Amanatidis, G. T., Paliatsos, A. G., Repapis, C. C., and Barttzis, J. G.: Decreasing precipitation trend in the Marathon area, Greece, Int. J. Climatol., 13(2), 191-201, doi:10.1002/joc.3370130205, 1993.

Aronica, G., Cannarozzo, M., and Noto, L.: Investigating the changes in extreme rainfall series recorded in urbanized area, Water Sci. Technol., 45, 49-54, 2002.

Boyles, R. P. and Raman, S.: Analysis of climate trends in North Carolina (1949-1998), Environment Int., 29, 263-275, 2003.

Brunetti, M., Maugeri, M., and Nanni, T.: Atmospheric circulation and precipitation in Italy for the last 50 years, Int. J. Climatol. 22(12), 1455-1471, doi:10.1002/joc.805, 2002a.

Brunetti, M., Maugeri, M., and Nanni, T.: Droughts and extreme events in regional daily Italian precipitation series, Int. J. Climatol., 22(5), 543-558, doi:10.1002/joc.751, 2002b.
Brunetti, M., Buffoni, L., Mangianti, F., Maugeri, M., and Nanni, T.: Temperature, precipitation and extreme events during the last century in Italy, Global Planet. Change, 40, 141-149, doi:10.1016/S0921-8181(03)00104-8, 2004.

Brunetti, M., Maugeri, M., Monti, F., and Nanni T.: Temperature and precipitation variability in Italy in the last two centuries from homogenised instrumental time series, Int. J. Climatol., 26(3), 345-381, doi:10.1002/joc.1251, 2006a.

Brunetti, M., Nanni, T., Maugeri, M., Auer, I., Boehm, R., and Schoener, W.: Precipitation variability and changes in the Greater Alpine Region over the 1800-2003 period, J. Geophys. Res.-Atmos., 111, D11107, doi:10.1029/2005JD006674, 2006 b.

Brunetti, M., Caloiero, T., Coscarelli, R., Gullà, G., Nanni, T., and Simolo, C.: Precipitation variability and change in the Calabria region (Italy) from a high resolution daily dataset, Int. J. Climatol., doi:10.1002/joc.2233, published online, 2010.

Caloiero, T., Coscarelli, R., Ferrari, E., and Mancini, M.: Trend detection of annual and seasonal rainfall in Calabria (Southern Italy), Int. J. Climatol., 31, 44-56, doi:10.1002/joc.2055, 2011.

Cancelliere, A. and Rossi, G.: Droughts in Sicily and comparison of identified droughts in Mediterranean regions, in: Tools for drought mitigation in Mediterranean regions, edited by: Rossi, G., Cancelliere, A., Pereira, L. S., Oweis, T., Shatanawi, M., and Zairi, A., Kluwer, Dordrecht, 103-122, 2003.

Cannarozzo, M., Noto, L. V., and Viola, F.: Spatial distribution of rainfall trends in Sicily (1921-2000), Phys. Chem. Earth, 31(18), 1201-1211, doi:10.1016/j.pce.2006.03.022, 2006.

Colacino, M., Conte, M., and Piervitali, E.: Elementi di climatologia della Calabria, IFA-CNR, Roma, 1997.

Conte, M., Giuffrida, S., and Tedesco, S.: The Mediterranean oscillation: impact on precipitation and hydrology in Italy, in: Proceedings of the Conference on Climate and Water, Publications of Academy of Finland, 1, 121-137, 1989.

Coscarelli, R., Gaudio, R., and Caloiero, T.: Climatic trends: an investigation for a Calabrian basin (southern Italy), in: Proceedings of the International Symposium The basis of civilization. Water science?, IAHS Publ., 286, 255-266, 2004.

Cotecchia, V., Casarano, D., and Polemio, M.: Characterization of rainfall trend and drought periods in Southern Italy from 1821 to 2001, in: Proceedings of 1st Italian-Russian Workshop New Trends in Hydrology, CNR Publ., 2823, 139-150, 2004.

Craddock, J. M.: Methods of comparing annual rainfall records for climatic purposes, Weather, 34, 332-346, 1979.

De Luis, M., Raventos, J., Gonzalez-Hidalgo, J. C., Sanchez, J. R., and Cortina, J.: Spatial analysis of rainfall trends in the region of Valencia (East of Spain), Int. J. Climatol., 20(12), 1451-1469, 2000.

De Michele, C., Montanari, A., and Rosso, R.: The effect of nonstationarity on the evaluation of critical design storms, Water Sci. Technol., 37(11), 187-193, doi:10.1016/S0273-1223(98)00332$1,1998$.

Del Rio, S., Herrero, L., Fraile, R., and Penas, A. P.: Spatial distribution of recent rainfall trends in Spain (1961-2006), Int. J. Climatol., doi:10.1002/joc.2111, in press, 2010.

Diodato, N.: Climatic fluctuations in Southern Italy since 17th century: reconstruction with precipitation records at Benevento, Climatic Change, 80(3-4), 411-431, doi:10.1007/s10584-0069119-1, 2007.

Esteban-Parra, M. J., Rodrigo, F. S., and Castro-Diez, Y.: Spatial 
and temporal patterns of precipitation in Spain for the period 1880-1992, Int. J. Climatol., 18(14), 1557-1574, 1998.

Federico, S., Dalu, G. A., Bellecci, C., and Colacino, M.: Mesoscale energetics and flows induced by sea-land and mountain-valley contrasts, Ann. Geophys., 18, 235-246, doi:10.1007/s00585-000-0235-3, 2000.

Federico, S., Bellecci, C., and Colacino, M.: Quantitative precipitation of the Soverato flood: the role of orography and surface fluxes, Nuovo Cimento C, 26, 7-22, 2003a.

Federico, S., Bellecci, C., and Colacino, M.: Numerical simulation of Crotone flood: storm evolution, Nuovo Cimento C, 26, 357371, 2003b.

Federico, S., Avolio, E., Bellecci, C., Lavagnini, A., and Walko, R. L.: Predictability of intense rain storms in the Central Mediterranean basin: sensitivity to upper-level forcing, Adv. Geosci., 12, 5-18, doi:10.5194/adgeo-12-5-2007, 2007.

Feidas, H., Noulopoulou, Ch., Makrogiannis, T., and Bora-Senta, E.: Trend analysis of precipitation time series in Greece and their relationship with circulation using surface and satellite data: 1955-2001, Theor. Appl. Climatol., 87, 155-177, doi:10.1007/s00704-006-0200-5, 2007.

Ferrari, E. and Terranova, O.: Non-parametric detection of trends and change point years in monthly and annual rainfalls, in: Proceedings of 1st Italian-Russian Workshop New Trends in Hydrology, CNR Publ., 2823, 177-188, 2004.

Hamilton, J. P., Whitelaw, G. S., and Fenech, A.: Mean annual temperature and annual precipitation trends at Canadian biosphere reserves, Environ. Monit. Assess., 67, 239-275, 2001.

Hess, T. M., Stephens, W., and Maryah, U. M.: Rainfall trends in the North East Arid Zone of Nigeria 1961-1990, Agr. Forest Meteorol., 74, 87-97, doi:10.1016/0168-1923(94)02179-N, 1995.

Hurrell, J. W.: Decadal trends in the North Atlantic Oscillation: Regional temperatures and precipitation, Science, 269(5224), 676679, doi:10.1126/science.269.5224.676, 1995.

Hurrell, J. W. and Van Loon, H.: Decadal variations in climate associated with the North Atlantic Oscillation, Climatic Change, 36, 301-326, doi:10.1023/A:1005314315270, 1997.

Kendall, M. G.: Rank Correlation Methods, Hafner Publishing Company, New York, 1962.

Kutiel, H., Maheras, P., and Guika, S.: Circulation and extreme rainfall conditions in the eastern Mediterranean during the last century, Int. J. Climatol., 16, 73-92, 1996.

Lebel, T. and Ali, A.: Recent trends in the Central and Western Sahel rainfall regime (1990-2007), J. Hydrol., 375, 52-64, doi:10.1016/j.jhydrol.2008.11.030, 2009.

Liu, Q., Yang, Z., and Cui, B.: Spatial and temporal variability of annual precipitation during 1961-2006 in Yellow River Basin, China, J. Hydrol., 361, 330-338, doi:10.1016/j.jhydrol.2008.08.002, 2008.

Longobardi, A. and Villani, P.: Trend analysis of annual and seasonal rainfall time series in the Mediterranean area, Int. J. Climatol., 30(10), 1538-1546, doi:10.1002/joc.2001, 2010.

Mann, H. B.: Nonparametric tests against trend, Econometrica, 13, 245-259, 1945.
Martin-Vide, J. and Lopez-Bustins, J. A.: The Western Mediterranean Oscillation and rainfall in the Iberian Peninsula, Int. J. Climatol., 26(11), 1455-1475, doi:10.1002/joc.1388, 2006.

Montanari, A., Rosso, R., and Taqqu, M. S.: Some long-run properties of rainfall records in Italy, J. Geophys. Res., 101(D23), 431-438, doi:10.1029/96JD02512, 1996.

Palmieri, S., Siani, A. M., and D’ Agostino, A.: Climate fluctuations and trends in Italy within the last hundred years, Ann. Geophys., 9, 769-776, 1991 http://www.ann-geophys.net/9/769/1991/.

Parker, D. E., Jones, P. D., Folland, C. K., and Bevan, A.: Interdecadal changes of surface temperature since the late nineteenth century, J. Geophys. Res., 99(D7), 14373-14399, doi:10.1029/94JD00548, 1994.

Peterson, T. C. and Easterling, D. R.: Creation of homogeneous composite climatological reference series, Int. J. Climatol., 14(6), 671-679, doi:10.1002/joc.3370140606, 1994.

Piccarreta, M., Capolongo, D., and Boenzi, F.: Trend analysis of precipitation and drought in Basilicata from 1923 to 2000 within a Southern Italy context, Int. J. Climatol., 24(7), 907-922, doi:10.1002/joc.1038, 2004.

Piervitali, E., Colacino, M., and Conte, M.: Rainfall over the Central-Western Mediterranean basin in the period 1951-1995. Part I: precipitation trends, Il Nuovo Cimento, 21, 331-344, 1998.

Ropelewski, C. F. and Jones, P. D.: An extension of the TahitiDarwin Southern Oscillation Index, Mon. Weather Rev., 115(9), 2161-2165, 1987.

Sharma, K. P., Moore III, B., and Vorosmarty, C. J.: Anthropogenic, climatic, and hydrologic trends in the Kosi basin, Himalaya, Climatic Change, 47, 141-165, doi:10.1023/A:1005696808953, 2000.

Slonosky, V. C., Jones, P. D., and Davies, T. D.: Atmospheric circulation and surface temperature in Europe from the 18th century to 1995, Int. J. Climatol., 21, 63-75, doi:10.1002/joc.591, 2001.

Spearman, C.: The proof and measurement of association between two things, Amer. J. Psychol., 15, 72-101, 1904.

Thompson, D. W. J. and Wallace, J. M.: The arctic oscillation signature in the wintertime geopotential height and temperature fields, Geophys. Res. Lett., 25(9), 1297-1300, doi:10.1029/98GL00950, 1998.

Thompson, D. W. J. and Wallace, J. M.: Annular modes in the extratropical circulation. Part I: month to month variability, J. Climate, 13, 1000-1016, 2000.

Türkeş, M. and Erlat, E.: Precipitation changes and variability in Turkey linked to the North Atlantic Oscillation during the period 1930-2000, Int. J. Climatol., 23, 1771-1796, doi:10.1002/joc.962, 2003.

Wallace, J. M. and Gutzler, D. S.: Teleconnections in the geopotential height field during the Northern Hemisphere winter, Mon Weather Rev., 109, 784-812, 1981.

Xoplaki, E., Luterbacher, J., and González-Rouco, J. F.: Mediterranean summer temperature and winter precipitation, large-scale dynamics, trends, Il Nuovo Cimento C, 29, 45-54, 2006. 